\title{
Formation of LPSO Phases in As-Cast Mg-Al-Zn-Gd Quaternary Alloys*1
}

\author{
Kazuki Masaoka ${ }^{1, * 2}$, Tadayuki Yamada ${ }^{1, * 3}$, Toshiaki Horiuchi ${ }^{2}$, Takaomi Itoi ${ }^{3}$ and Seiji Miura ${ }^{4}$ \\ ${ }^{1}$ Hokkaido University of Science, Sapporo 006-8585, Japan \\ ${ }^{2}$ Laboratory of Advanced Materials for Cold Region (LAM), Hokkaido University of Science, Sapporo 006-8585, Japan \\ ${ }^{3}$ Faculty of Engineering, Chiba University, Chiba 263-8522, Japan \\ ${ }^{4}$ Faculty of Engineering, Hokkaido University, Sapporo 060-8628, Japan
}

\begin{abstract}
$\mathrm{Mg}$ alloys with a long-period stacking-order (LPSO) phase are categorized into two types. Those in which the LPSO phase forms in as-cast state are referred to as Type I, while those in which the LPSO phase does not appear until a heat treatment is performed are categorized as Type II. However, the reason that gives rise to these two types of alloy is still not well understood. In the present study, in an attempt to clarify this issue, three different $\mathrm{Mg}_{85}(\mathrm{Al}, \mathrm{Zn})_{6} \mathrm{Gd}_{9}$ quaternary alloys were prepared. The $\alpha$ - $\mathrm{Mg}, \mathrm{Al}_{2} \mathrm{Gd}_{,} \mathrm{Mg}_{3} \mathrm{Gd}$ and LPSO phases were identified in the as-cast quaternary alloys by microstructural observations, composition analysis and crystal structure analysis using electron probe microanalysis

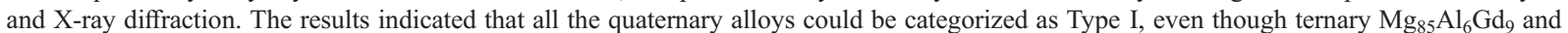
$\mathrm{Mg}_{85} \mathrm{Zn}_{6} \mathrm{Gd}_{9}$ alloys were Type II. The crystal structure of the LPSO phase in the as-cast alloys is considered to be18R with dilute solute elements, and the fraction of this phase increases with increasing $\mathrm{Zn}$ content. The presence of this phase is thought to be the cause of destabilization of the primary $\mathrm{Al}_{2} \mathrm{Gd}$ phase. It is thus concluded that the relative stability of phases in the vicinity of the LPSO phase is crucial in determining the type of Mg alloy formed. [doi:10.2320/matertrans.MT-MM2019008]
\end{abstract}

(Received October 9, 2019; Accepted December 16, 2019; Published February 17, 2020)

Keywords: magnesium alloy, long period stacking order, magnesium-aluminum-zinc-gadolinium quaternary alloy, formation type

\section{Introduction}

Due to their low density (about $25 \%$ of that of Fe and $66 \%$ of that of $\mathrm{Al}), \mathrm{Mg}$ alloys are being actively investigated as structural materials for automotive and aviation applications. In 2001, Kawamura et al. developed a Mg-1Zn-2Y (at\%) alloy with a very high strength of $610 \mathrm{MPa}$ and $5 \%$ tensile elongation using a special fabrication process. ${ }^{1)}$ These characteristics were attributed to the coexistence of a longperiod stacking-order (LPSO) phase and an $\alpha$-Mg phase. ${ }^{2)}$ Consequently, Mg alloys containing a LPSO phase have attracted a large amount of attention in recent years. ${ }^{3-8)}$

The LPSO phase has a unique crystal structure consisting of stacked HCP Mg layers interspersed with stacked FCC layers containing isolated $\mathrm{L1}_{2}$-type clusters composed of transition metal (TM) and rare-earth (RE) elements in a ratio of 3:4. ${ }^{9)}$ The number of HCP-Mg layers varies from 0 to 4 , and the corresponding polymorphic crystal structures are referred to as $12 \mathrm{R}, 10 \mathrm{H}, 18 \mathrm{R}, 14 \mathrm{H}$ and $24 \mathrm{R}$, respectively.

There are two different types of LPSO phase. The Type I phase in the $\mathrm{Mg}-\mathrm{Zn}-\mathrm{Y}$ and $\mathrm{Mg}-\mathrm{Zn}-\mathrm{Dy}$ systems forms during casting, whereas the Type II phase in the $\mathrm{Mg}-\mathrm{Zn}-\mathrm{Tb}$ system does not appear in the as-cast state, but forms during heat treatment. ${ }^{10)}$ The type of LPSO phase that is formed is thought to be related to its stability relative to other phases in the alloy. To fully control the microstructure, the additive elements used and the type of LPSO phases present are essential factors.

In ternary $\mathrm{Mg}-\mathrm{Al}-\mathrm{Gd}$ alloys, a Type II 18R-LPSO phase appears during heat treatment, while the primary phases are $\alpha-\mathrm{Mg}$ and $\mathrm{Al}_{2} \mathrm{Gd}$. A $14 \mathrm{H}-\mathrm{LPSO}$ phase has been reported in as-cast $\mathrm{Mg}_{96.5} \mathrm{Zn}_{1} \mathrm{Gd}_{2.5}$ alloy. ${ }^{11)}$ However, Yamasaki et al.

\footnotetext{
${ }^{* 1}$ This Paper was Originally Published in Japanese in J. Japan Inst. Met. Mater. 83 (2019) 257-263.

${ }^{* 2}$ Graduate Student, Hokkaido University of Science

${ }^{*}$ Undergraduate Student, Hokkaido University of Science. Present address: MEITEC Corp., Tokyo 110-0005, Japan
}

and Miyakawa et al. found no LPSO phases in as-cast ternary $\mathrm{Mg}-\mathrm{Zn}-\mathrm{Gd}$ alloys, ${ }^{6,12,13)}$ but reported the formation of a 14H-LPSO phase during heat treatment. Therefore, both ends of the series of $\mathrm{Mg}-\mathrm{Al}-\mathrm{Zn}-\mathrm{Gd}$ quaternary alloys, i.e., $\mathrm{Mg}_{85} \mathrm{Al}_{6} \mathrm{Gd}_{9}$ and $\mathrm{Mg}_{85} \mathrm{Zn}_{6} \mathrm{Gd}_{9}$, are Type II LPSO phases.

Based on the structure of the $\mathrm{L}_{2}$ clusters composed of TM and RE elements formed in the LPSO phase, it is expected that $\mathrm{Al}$ and $\mathrm{Zn}$ occupy the same sites. However, there is no information available for LPSO phases composed of $\mathrm{Mg}, \mathrm{Al}$, $\mathrm{Zn}$ and Gd. Miura et al. performed an experimental study on the substitutional behavior of $\mathrm{RE}$ elements in $\mathrm{Mg}-\mathrm{Zn}-\mathrm{RE}$ $(\mathrm{RE}=\mathrm{Y}, \mathrm{Dy}, \mathrm{Gd}, \mathrm{Ho}, \mathrm{Ce})$ systems, and found that it is strongly affected by interaction between RE elements, i.e., no interaction between RE elements seems to be a criterion for full substitution. In the binary $\mathrm{Al}-\mathrm{Zn}$ system, the solubility of $\mathrm{Zn}$ in FCC-Al is high, and no intermetallic compound is formed. ${ }^{14)}$ This strongly suggests a weak interaction between $\mathrm{Al}$ and $\mathrm{Zn}$, and the stability of the quaternary $\mathrm{Mg}-(\mathrm{Al}, \mathrm{Zn})-\mathrm{Gd}$ LPSO phases is considered to be similar to that of the ternary $\mathrm{Mg}-\mathrm{Al}-\mathrm{Gd}$ and $\mathrm{Mg}-\mathrm{Zn}-\mathrm{Gd}$ LPSO phases. On the other hand, the primary phases in the ternary $\mathrm{Mg}-\mathrm{Al}-\mathrm{Gd}$ alloy are different from those in the $\mathrm{Mg}-$ $\mathrm{Zn}-\mathrm{Gd}$ alloy, which implies that the stability of the primary phases may depend on the alloy composition. In the present study, $\mathrm{Mg}-\mathrm{Al}-\mathrm{Zn}-\mathrm{Gd}$ quaternary alloys are employed to investigate the solidification process and the type of LPSO phases formed. The quaternary $\mathrm{Mg}-(\mathrm{Al}, \mathrm{Zn})-\mathrm{Gd}$ LPSO phases are also investigated to determine the main factors responsible for their formation.

\section{Experimental Procedure}

The alloy composition was $\mathrm{Mg}_{85}(\mathrm{Al}, \mathrm{Zn})_{6} \mathrm{Gd}_{9}$ with an $\mathrm{Al} /$ $\mathrm{Zn}$ ratio of 2.0, 1.0 or 0.5 . Alloy ingots with a weight of about $30 \mathrm{~g}$ were prepared from high-purity raw materials (99.95\% Mg, 99.99\% Al, 99.5\% Zn and 99.9\% Gd) in highpurity graphite crucibles. The crucibles were placed in an 
Ar-filled induction heater, and the contents were cast in a mild steel mold. A part of each ingot was subsequently encapsulated in a glass tube filled with $\mathrm{Ar}$ gas and isothermally heat-treated at $450^{\circ} \mathrm{C}$ for $1000 \mathrm{~h}$, followed by water quenching. As-cast and heat-treated samples were cut into small pieces and polished. The microstructure was investigated by scanning electron microscopy (SEM) in conjunction with electron probe microanalysis (EPMA; JXA8230 , JEOL, Tokyo) with an accelerating voltage of $15 \mathrm{kV}$. The probe current was $5 \times 10^{-10} \mathrm{~A}$ for SEM observations and $3 \times 10^{-8} \mathrm{~A}$ for wavelength dispersive X-ray spectroscopy (WDS). X-ray diffraction (XRD; SmartLab, Rigaku, Tokyo) analysis using a copper target with an X-ray tube voltage of $40 \mathrm{kV}$ and a tube current of $35 \mathrm{~mA}$ was also conducted to identify the LPSO phases.

\section{Results and Discussion}

\subsection{As-cast alloys}

Figure 1 shows backscattered electron images of the as-cast alloys $\mathrm{Mg}_{85} \mathrm{Al}_{4} \mathrm{Zn}_{2} \mathrm{Gd}_{9}, \quad \mathrm{Mg}_{85} \mathrm{Al}_{3} \mathrm{Zn}_{3} \mathrm{Gd}_{9}$ and $\mathrm{Mg}_{85} \mathrm{Al}_{2} \mathrm{Zn}_{4} \mathrm{Gd}_{9}$, hereafter denoted $4 \mathrm{Al} 2 \mathrm{Zn}, 3 \mathrm{Al} 3 \mathrm{Zn}$ and 2Al4Zn alloys, respectively. Each image contains black, white, lamellar and plate-like regions. No significant differences are observed among the alloys, although the amount of plate-like regions increases with increasing $\mathrm{Zn}$ content. Figure 2 shows the results of a WDS analysis of 300 randomly selected points (white circles) together with gray circles indicating the results of point analyses on the black, white, lamellar and plate-like regions in each alloy on the $\mathrm{Mg}-(\mathrm{Al}, \mathrm{Zn})-\mathrm{Gd}$ ternary section of the quaternary system. The broken line representing a $(\mathrm{Al}+\mathrm{Zn}): \mathrm{Gd}$ ratio of $3: 4$ indicates the stoichiometric ratio of TM to RE for LPSO phase polymorphs.

The average chemical compositions (at\%) of the black, white, lamellar and plate-like regions in the as-cast alloys are shown in Table 1. It should be noted that the results for the lamellar region represent weighted average chemical compositions of the two-phase lamellar microstructure because the lamellar region has a fine microstructure that is beyond the spatial resolution of SEM-WDS. For all the alloys, the black regions contain mostly $\mathrm{Mg}$, while the $\mathrm{Mg}$ content in the lamellar regions is about $87 \%$, and the $\mathrm{Al}: \mathrm{Gd}$ ratio in the white regions is about $1: 2$. This suggests that the black and white regions are the $\alpha-\mathrm{Mg}$ and $\mathrm{Al}_{2} \mathrm{Gd}$ phases, respectively. The average chemical compositions of the plate-like structures fall on the broken line, suggesting the LPSO phase. It is noteworthy that the average chemical compositions of the lamellar regions in all the alloys are similar and almost no $\mathrm{Al}$ is soluble.

Figure 3 shows the results of XRD analyses $\left(2 \theta=10-90^{\circ}\right)$ of the as-cast alloys. Peaks associated with $\mathrm{Mg}, \mathrm{Al}_{2} \mathrm{Gd}$ and $\mathrm{Mg}_{3} \mathrm{Gd}$ are seen to be present. Therefore, the fine lamellar region is considered to be composed of $\mathrm{Mg}_{3} \mathrm{Gd}$ (white) and $\mathrm{Mg}$ (black).

Figure 4 shows XRD patterns in the range $2 \theta=4-10^{\circ}$ to identify the polymorphic LPSO phases. The peak angles for (000n) reflections for each LPSO structure calculated based on the lattice constant $\mathrm{c}$ for pure $\mathrm{Mg}$ are tabulated in Table 2 (n for $10 \mathrm{H}, 18 \mathrm{R}, 14 \mathrm{H}, 24 \mathrm{R}$ is $2,3,2$ and 3 , respectively). The
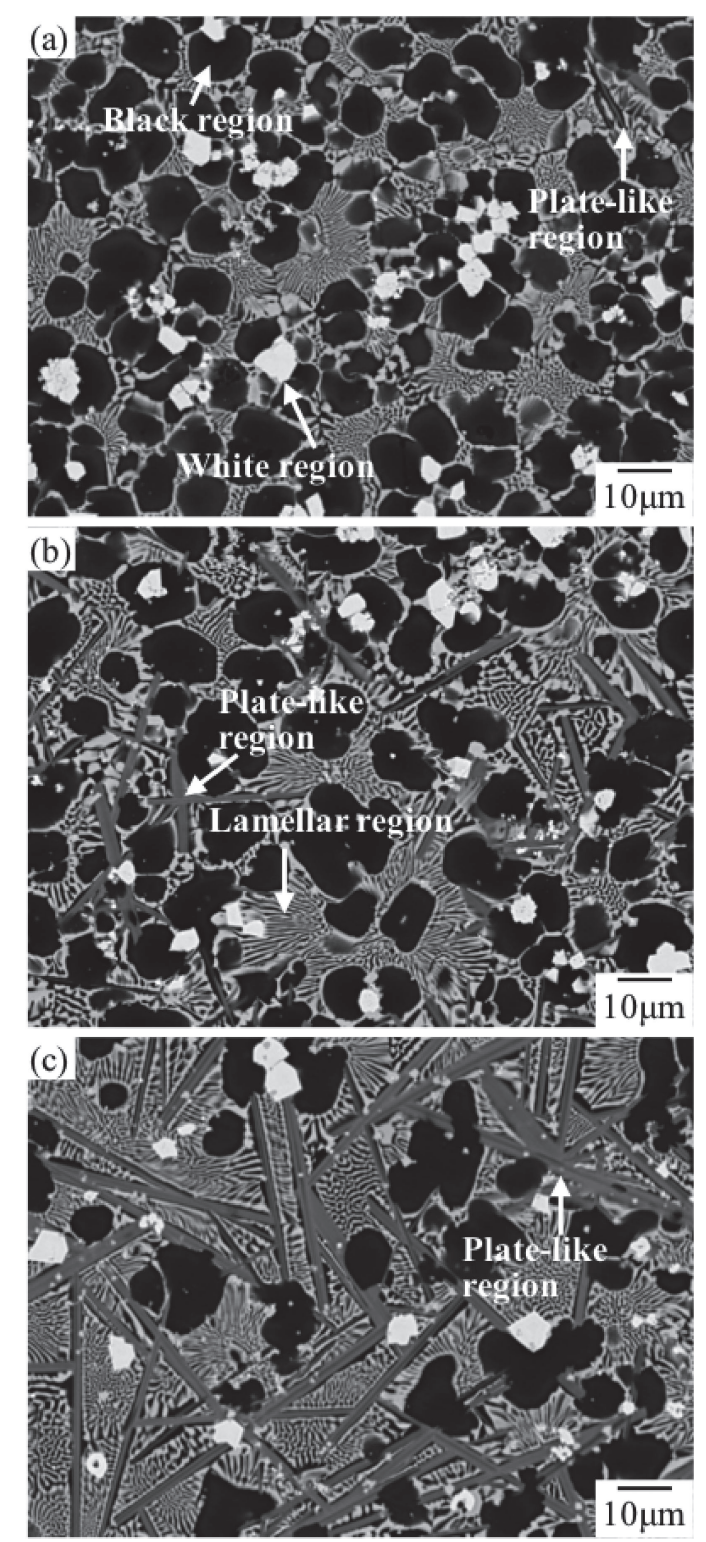

Fig. 1 Backscattered electron images of as-cast (a) $\mathrm{Mg}_{85} \mathrm{Al}_{4} \mathrm{Zn}_{2} \mathrm{Gd}_{9}$, (b) $\mathrm{Mg}_{85} \mathrm{Al}_{3} \mathrm{Zn}_{3} \mathrm{Gd}_{9}$ and (c) $\mathrm{Mg}_{85} \mathrm{Al}_{2} \mathrm{Zn}_{4} \mathrm{Gd}_{9}$ alloys. Each image contains black, white, lamellar and plate-like regions.

$18 \mathrm{R}$ structure is confirmed to be present in the as-cast 2Al4Zn alloy. On the other hand, none of the low-angle peaks listed in Table 2 are present for the $4 \mathrm{Al} 2 \mathrm{Zn}$ or $3 \mathrm{Al} 3 \mathrm{Zn}$ alloy, in spite of the existence of similar plate-like structures to those in the 2Al4Zn alloy. The amount of plate-like structures in the $4 \mathrm{Al} 2 \mathrm{Zn}$ and $3 \mathrm{Al} 3 \mathrm{Zn}$ alloys is apparently much smaller than that in the $2 \mathrm{Al}$ ZZn alloy, leading to an absence of low-angle XRD peaks. However, these quaternary alloys containing both $\mathrm{Al}$ and $\mathrm{Zn}$ should be classified as Type I. Egusa et al. reported that the stoichiometric composition of the $18 \mathrm{R}$ LPSO phase is $\mathrm{Mg}_{80.6} \mathrm{TM}_{8.3} \mathrm{RE}_{11.1},{ }^{9}$ ) while the chemical composition of the LPSO phases evaluated in the present study is about $\mathrm{Mg}_{90} \mathrm{TM}_{4} \mathrm{RE}_{6}$, as shown in Table 1. This discrepancy in chemical composition remains to be clarified in the future.

\subsection{Heat-treated alloys}

Figure 5 shows backscattered electron images of the heat- 

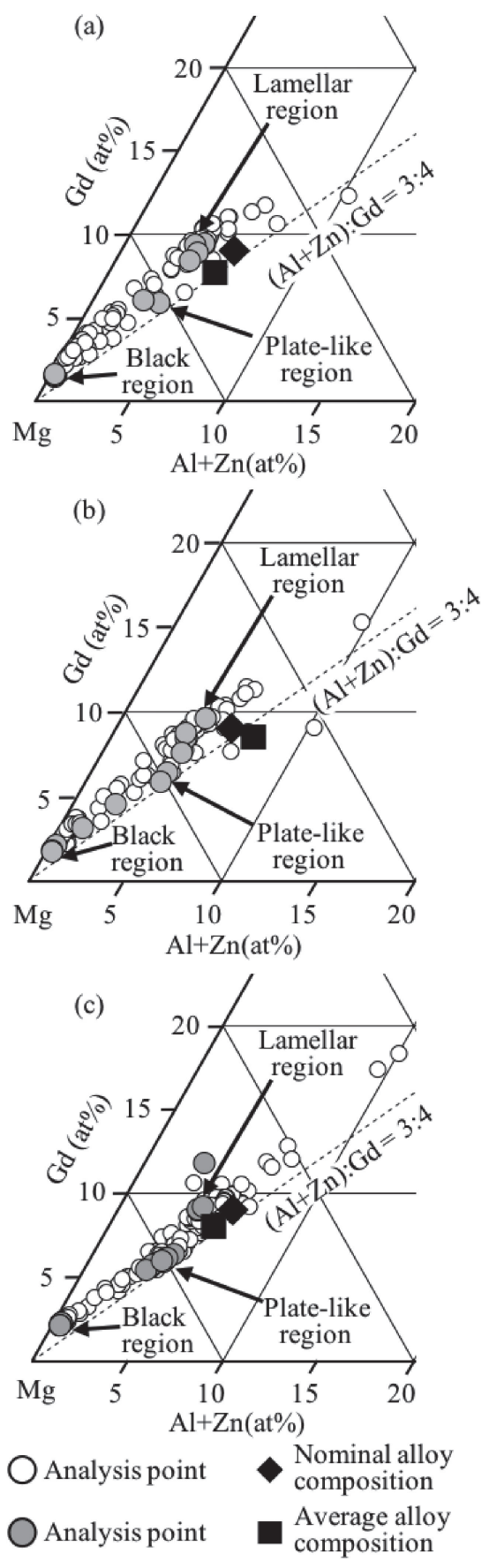

Fig. 2 Analyzed chemical compositions of as-cast (a) $\mathrm{Mg}_{85} \mathrm{Al}_{4} \mathrm{Zn}_{2} \mathrm{Gd}_{9}$, (b) $\mathrm{Mg}_{85} \mathrm{Al}_{3} \mathrm{Zn}_{3} \mathrm{Gd}_{9}$ and (c) $\mathrm{Mg}_{85} \mathrm{Al}_{2} \mathrm{Zn}_{4} \mathrm{Gd}_{9}$ alloys. Chemical compositions for plate-like regions are located in the vicinity of a line with a $(\mathrm{Al}+\mathrm{Zn}): \mathrm{Gd}$ ratio of $3: 4$.

treated 4A12Zn, 3A13Zn and 2A14Zn alloys. Each image contains black, white, light gray and dark gray regions. The boundaries between the light gray and dark gray regions are unclear, and the amount of light gray regions decreases with increasing $\mathrm{Zn}$ content. Figure 6 shows the results of a WDS analysis of 300 randomly selected points (white circles) together with gray circles indicating the results of point analyses on the black, white, light gray and dark gray regions in each alloy on the $\mathrm{Mg}-(\mathrm{Al}, \mathrm{Zn})-\mathrm{Gd}$ ternary section of the quaternary system. The broken line indicates a $(\mathrm{Al}+\mathrm{Zn}): \mathrm{Gd}$ chemical composition ratio of 3:4. By averaging the 300
Table 1 Average chemical compositions (at\%) of the black, white, lamellar and plate-like regions in as-cast (a) $\mathrm{Mg}_{85} \mathrm{Al}_{4} \mathrm{Zn}_{2} \mathrm{Gd}_{9}$, (b) $\mathrm{Mg}_{85} \mathrm{Al}_{3} \mathrm{Zn}_{3} \mathrm{Gd}_{9}$ and (c) $\mathrm{Mg}_{85} \mathrm{Al}_{2} \mathrm{Zn}_{4} \mathrm{Gd}_{9}$ alloys. The results for the lamellar regions represent average chemical compositions of the lamellar microstructures.

\begin{tabular}{c||cccc}
\hline (a) $\mathrm{Mg}_{85} \mathrm{Al}_{4} \mathrm{Zn}_{2} \mathrm{Gd}_{9}$ & $\mathrm{Mg}$ & $\mathrm{Al}$ & $\mathrm{Zn}$ & $\mathrm{Gd}$ \\
\hline Black region & 98.2 & 0.0 & 0.2 & 1.6 \\
\hline White region & 9.9 & 53.9 & 2.3 & 33.9 \\
\hline Lamellar region & 87.8 & 0.4 & 3.3 & 8.5 \\
\hline Plate-like region & 90.6 & 1.2 & 2.3 & 5.9 \\
\hline \hline (b) $\mathrm{Mg}_{85} \mathrm{Al}_{3} \mathrm{Zn}_{3} \mathrm{Gd} 9$ & $\mathrm{Mg}$ & $\mathrm{Al}$ & $\mathrm{Zn}$ & $\mathrm{Gd}$ \\
\hline Black region & 97.7 & 0.0 & 0.3 & 2.0 \\
\hline White region & 9.6 & 52.9 & 3.3 & 34.2 \\
\hline Lamellar region & 87.1 & 0.5 & 3.5 & 8.9 \\
\hline Plate-like region & 92.4 & 0.7 & 2.0 & 4.9 \\
\hline \hline (c) Mgg $\mathrm{Al}_{2} \mathrm{Zn} \mathrm{Gd}_{4} \mathrm{Gd}$ & $\mathrm{Mg}$ & $\mathrm{Al}$ & $\mathrm{Zn}$ & $\mathrm{Gd}$ \\
\hline Black region & 97.5 & 0.0 & 0.3 & 2.2 \\
\hline White region & 13.8 & 46.4 & 5.6 & 34.2 \\
\hline Lamellar region & 86.3 & 0.4 & 3.6 & 9.8 \\
\hline Plate-like region & 90.2 & 1.1 & 2.7 & 6.0 \\
\hline
\end{tabular}

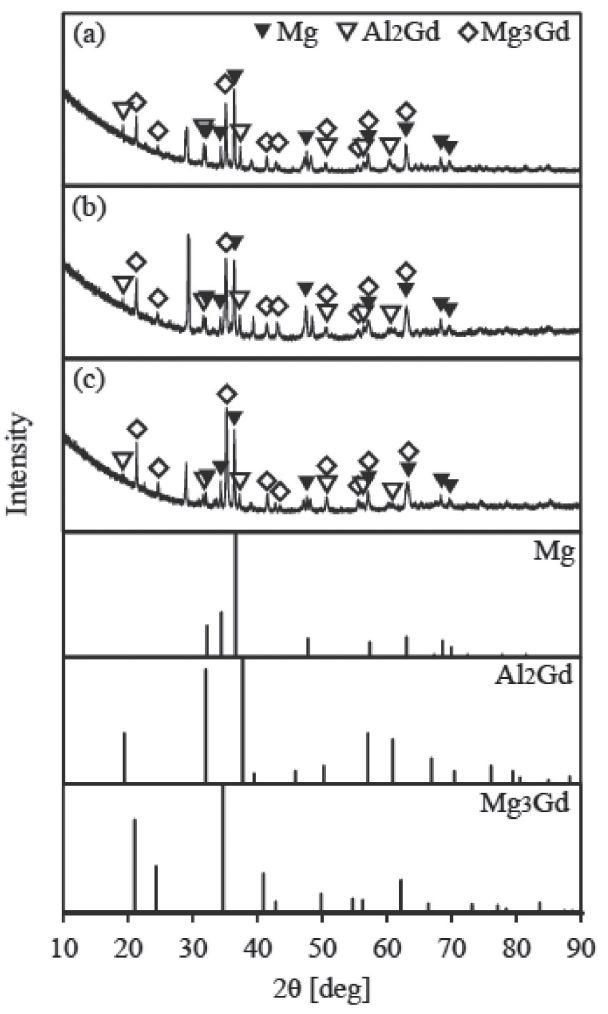

Fig. 3 X-ray diffraction patterns $\left(10-90^{\circ}\right)$ for as-cast (a) $\mathrm{Mg}_{85} \mathrm{Al}_{4} \mathrm{Zn}_{2} \mathrm{Gd}_{9}$, (b) $\mathrm{Mg}_{85} \mathrm{Al}_{3} \mathrm{Zn}_{3} \mathrm{Gd}_{9}$ and (c) $\mathrm{Mg}_{85} \mathrm{Al}_{2} \mathrm{Zn}_{4} \mathrm{Gd}_{9}$ alloys.

randomly selected points, the chemical compositions for the $4 \mathrm{Al} 2 \mathrm{Zn}, 3 \mathrm{Al} 3 \mathrm{Zn}$ and $2 \mathrm{Al} 4 \mathrm{Zn}$ alloys are estimated to be $\mathrm{Mg}_{86.4} \mathrm{Al}_{3.6} \mathrm{Zn}_{2.1} \mathrm{Gd}_{7.9}, \quad \mathrm{Mg}_{85.5} \mathrm{Al}_{3.0} \mathrm{Zn}_{3.0} \mathrm{Gd}_{8.5}$ and 

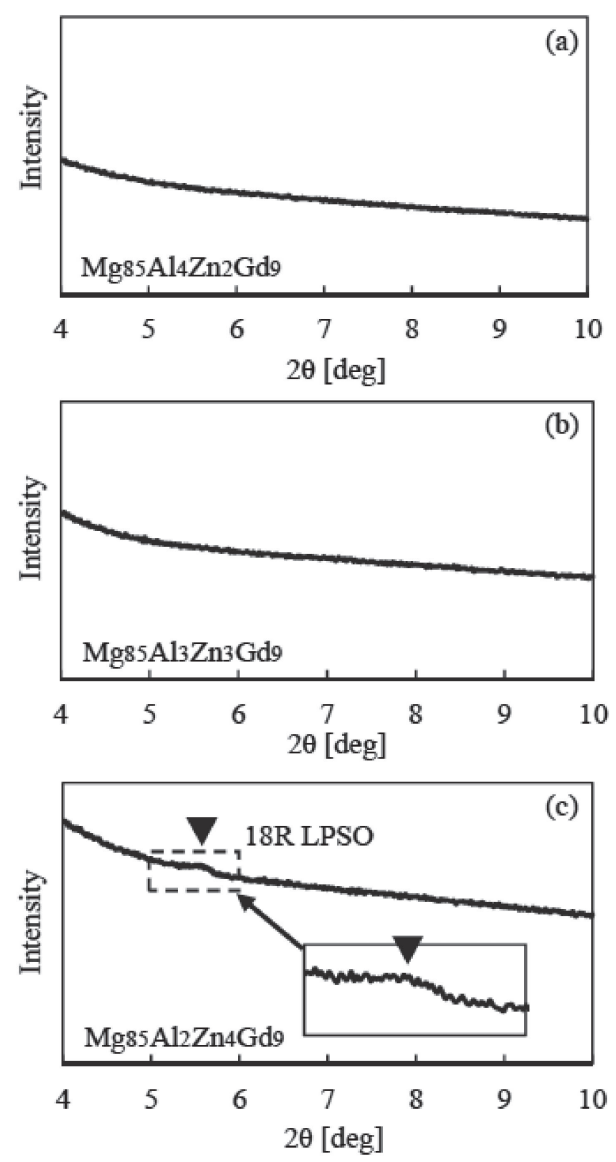

Fig. $4 \mathrm{X}$-ray diffraction patterns $\left(4-10^{\circ}\right.$ ) for as-cast (a) $\mathrm{Mg}_{85} \mathrm{Al}_{4} \mathrm{Zn}_{2} \mathrm{Gd}_{9}$, (b) $\mathrm{Mg}_{85} \mathrm{Al}_{3} \mathrm{Zn}_{3} \mathrm{Gd}_{9}$ and (c) $\mathrm{Mg}_{85} \mathrm{Al}_{2} \mathrm{Zn}_{4} \mathrm{Gd}_{9}$ alloys.

Table 2 XRD peak positions (000n) for each LPSO structure calculated based on the lattice constant for pure $\mathrm{Mg}$. The value of $\mathrm{n}$ for $10 \mathrm{H}, 18 \mathrm{R}$, $14 \mathrm{H}$ and $24 \mathrm{R}$ is $2,3,2$ and 3, respectively.

\begin{tabular}{cc}
\hline LPSO structure & $2 \theta[\mathrm{deg}]$ \\
\hline $10 \mathrm{H}$ & 6.78 \\
\hline $18 \mathrm{R}$ & 5.66 \\
\hline $14 \mathrm{H}$ & 4.84 \\
\hline $24 \mathrm{R}$ & 4.24
\end{tabular}

$\mathrm{Mg}_{85.7} \mathrm{Al}_{2.0} \mathrm{Zn}_{4.0} \mathrm{Gd}_{8.3}$, respectively. The nominal and estimated chemical compositions of the alloys are also indicated in Figs. 2 and 6. The average chemical compositions of the black, white, light gray and dark gray regions in the heattreated alloys are shown in Table 3. For all the alloys, the black regions contain mostly $\mathrm{Mg}$, and the $\mathrm{Al}: \mathrm{Gd}$ ratios in the white regions are about $1: 2$. Therefore, it is concluded that the black and white regions are the $\alpha-\mathrm{Mg}$ and $\mathrm{Al}_{2} \mathrm{Gd}$ phases, respectively. The light gray and dark gray regions are considered to be LPSO phases because their chemical compositions are located in the vicinity of the broken lines. Hereafter, the dark gray and light gray regions are denoted as LPSO (1) and LPSO (2), respectively. It is also noteworthy that the lamellar regions found in the as-cast alloys are not present.
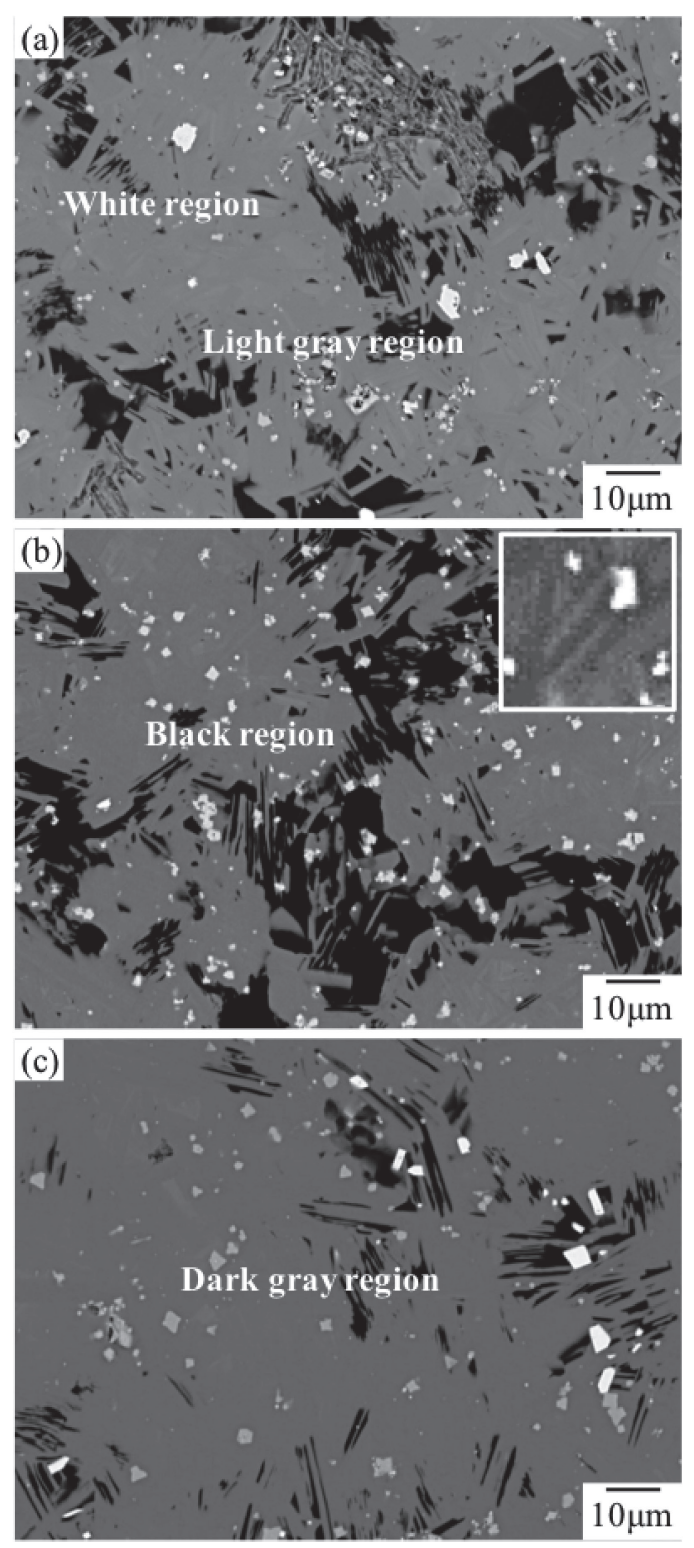

Fig. 5 Backscattered electron images of (a) $\mathrm{Mg}_{85} \mathrm{Al}_{4} \mathrm{Zn}_{2} \mathrm{Gd}_{9}$, (b) $\mathrm{Mg}_{85} \mathrm{Al}_{3} \mathrm{Zn}_{3} \mathrm{Gd}_{9}$ and (c) $\mathrm{Mg}_{85} \mathrm{Al}_{2} \mathrm{Zn}_{4} \mathrm{Gd}_{9}$ alloys after isothermal heat treatment at $450^{\circ} \mathrm{C}$ for $1000 \mathrm{~h}$. Each image contains black, white, light gray, and dark gray regions.

Figure 7 shows XRD patterns in the range $2 \theta=4-10^{\circ}$ for each heat-treated alloy. As is clear from Table 2, both the $14 \mathrm{H}\left(2 \theta=4.8^{\circ}\right)$ and $18 \mathrm{R}\left(\theta=5.6^{\circ}\right)$ structures are present in each alloy, whereas the $14 \mathrm{H}$ structure is not found in the ascast alloys. The peak intensity for the $14 \mathrm{H}$ structure becomes much larger than that for the $18 \mathrm{R}$ structure with increasing $\mathrm{Zn}$ content. As shown in Fig. 5, the volume fraction of LPSO (1) also increases with increasing $\mathrm{Zn}$ content. Therefore, it is concluded that LPSO (1) and LPSO (2) represent the $14 \mathrm{H}$ and 18R LPSO phases, respectively. The peaks at around $9.2^{\circ}$ correspond to two-dimensional ordering of $\mathrm{Ll}_{2}$ clusters. ${ }^{15)}$ The Mg-TM-RE ratios for LPSO (1) in each alloy are summarized in Table 4 together with the stoichiometric ratios for the $14 \mathrm{H}$ and $18 \mathrm{R}$ LPSO phases. It is confirmed that the $\mathrm{Mg}-\mathrm{TM}-\mathrm{RE}$ ratio in LPSO (1) for all the alloys is close to that for the 14H LPSO phase, suggesting that LPSO (1) is an LPSO phase polymorph with a $14 \mathrm{H}$ structure. 

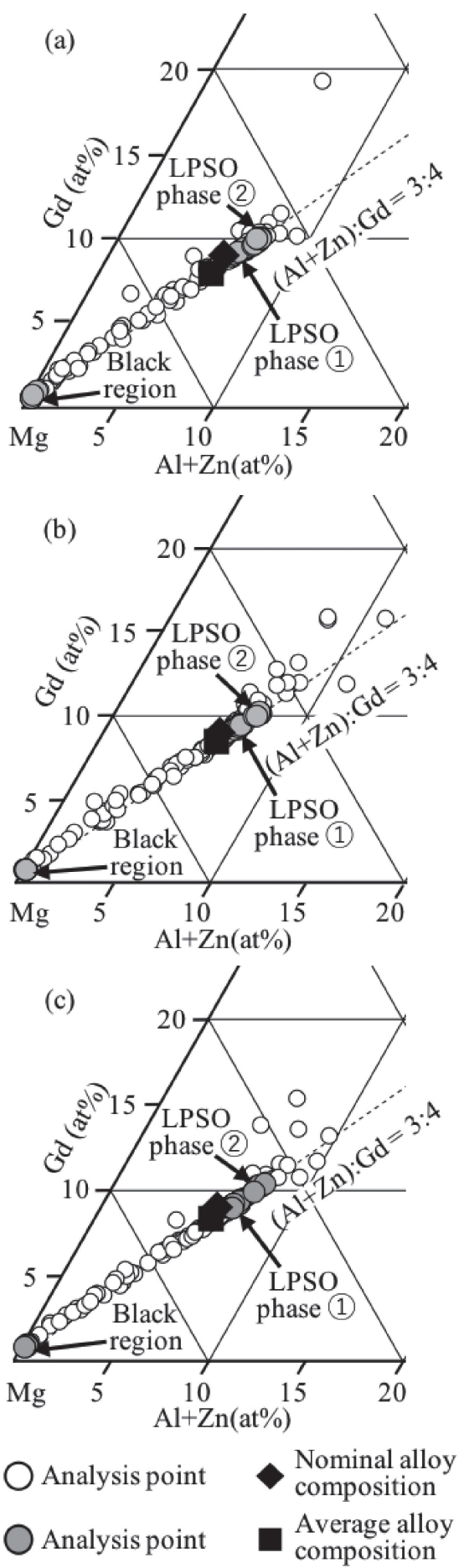

Fig. 6 Analyzed chemical compositions of (a) $\mathrm{Mg}_{85} \mathrm{Al}_{4} \mathrm{Zn}_{2} \mathrm{Gd}_{9}$, (b) $\mathrm{Mg}_{85} \mathrm{Al}_{3} \mathrm{Zn}_{3} \mathrm{Gd}_{9}$ and (c) $\mathrm{Mg}_{85} \mathrm{Al}_{2} \mathrm{Zn}_{4} \mathrm{Gd}_{9}$ alloys after isothermal heat treatment at $450^{\circ} \mathrm{C}$ for $1000 \mathrm{~h}$. Chemical compositions for LPSO (1) and LPSO (2) phases are located in the vicinity of the line with a $(\mathrm{Al}+\mathrm{Zn}): \mathrm{Gd}$ ratio of $3: 4$.

\subsection{Factors determining the formation of Type $I$ and Type II alloys}

Although the ternary $\mathrm{Mg}_{85} \mathrm{Al}_{6} \mathrm{Gd}_{9}$ and $\mathrm{Mg}_{85} \mathrm{Zn}_{6} \mathrm{Gd}_{9}$ alloys are Type $\mathrm{II}^{13,16)}$ the quaternary $\mathrm{Mg}_{85} \mathrm{Al}_{4-\mathrm{x}} \mathrm{Zn}_{2+\mathrm{x}} \mathrm{Gd}_{9}$ alloys are found to be Type I, for which an LPSO phase appears in the as-cast state. This is attributed to the higher stability of the LPSO phase compared to other competing phases. The $\mathrm{Al} / \mathrm{Zn}$ ratios for the phases in the heat-treated alloys and
Table 3 Average chemical compositions (at\%) of the black, white, light gray, gray and dark gray regions in (a) $\mathrm{Mg}_{85} \mathrm{Al}_{4} \mathrm{Zn}_{2} \mathrm{Gd}_{9}$, (b) $\mathrm{Mg}_{85} \mathrm{Al}_{3} \mathrm{Zn}_{3} \mathrm{Gd}_{9}$ and (c) $\mathrm{Mg}_{85} \mathrm{Al}_{2} \mathrm{Zn}_{4} \mathrm{Gd}_{9}$ alloys after isothermal heat treatment at $450^{\circ} \mathrm{C}$ for $1000 \mathrm{~h}$.

\begin{tabular}{|c|c|c|c|}
\hline (a) $\mathrm{Mg}_{85} \mathrm{Al}_{4} \mathrm{Zn}_{2} \mathrm{Gd}_{9}$ & $\mathrm{Mg} \quad \mathrm{Al}$ & $\mathrm{Zn}$ & Gd \\
\hline Black region & 99.1 & 0.1 & 0.8 \\
\hline White region & 11.452 .7 & 2.6 & 33.3 \\
\hline $\begin{array}{l}\text { Dark gray region } \\
\text { (LPSO(1)) }\end{array}$ & 4.3 & 2.7 & 9.5 \\
\hline $\begin{array}{l}\text { Light gray } \mathrm{r} \\
\text { (LPSO } 2\end{array}$ & 4.5 & 2.8 & 9.9 \\
\hline (b) $\mathrm{Mg}_{85} \mathrm{Al}_{3} \mathrm{Zn}_{3} \mathrm{Gd}_{9}$ & $\mathrm{Mg} \quad \mathrm{Al}$ & $\mathrm{Zn}$ & $\mathrm{Gd}$ \\
\hline Black region & 99.1 & 0.1 & 0.8 \\
\hline White region & 15.347 .8 & 4.5 & 32.4 \\
\hline $\begin{array}{l}\text { Dark gray region } \\
\text { (LPSO(1)) }\end{array}$ & 83.7 & 3.2 & 9.4 \\
\hline $\begin{array}{l}\text { Light gray region } \\
\text { (LPSO 2) }\end{array}$ & 82.5 & 3.4 & 10.1 \\
\hline (c) $\mathrm{Mg}_{85} \mathrm{Al}_{2} \mathrm{Zn}_{4} \mathrm{Gd}_{9}$ & $\mathrm{Mg}$ & $\mathrm{Zn}$ & Gd \\
\hline Black region & 98.9 & 0.2 & 0.9 \\
\hline White region & 12.047 .9 & 6.0 & 34.1 \\
\hline $\begin{array}{l}\text { Dark gray region } \\
\text { (LPSO(1)) }\end{array}$ & 84.1 & 4.3 & 9.2 \\
\hline $\begin{array}{l}\text { Light gray region } \\
\text { (LPSO(2)) }\end{array}$ & 82.3 & 4.3 & 10.2 \\
\hline
\end{tabular}
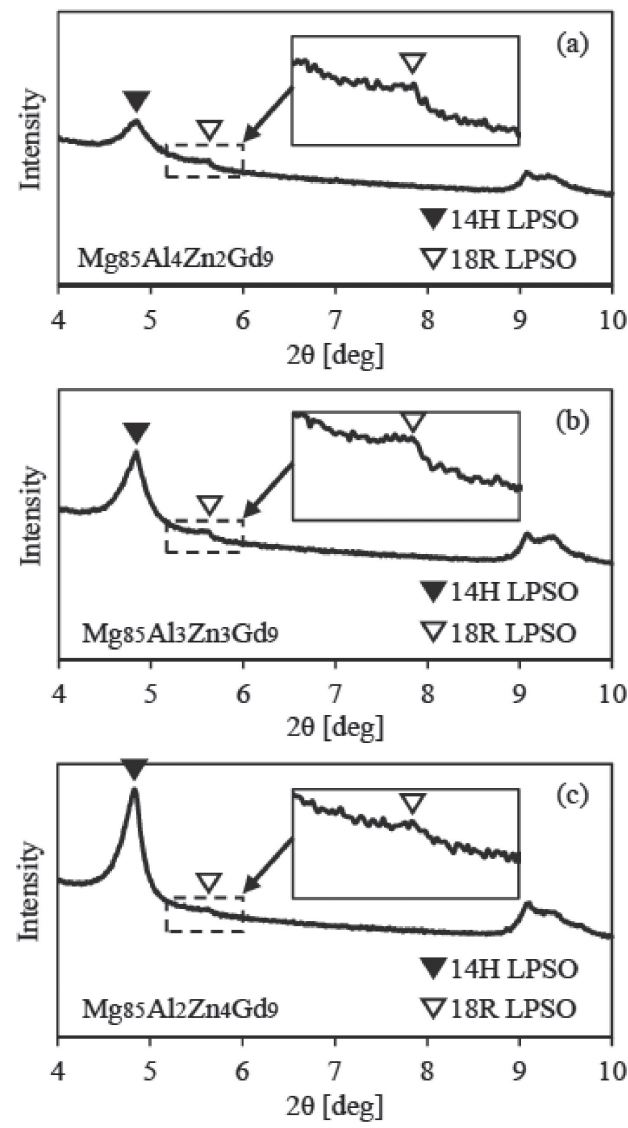

Fig. 7 X-ray patterns for (a) $\mathrm{Mg}_{85} \mathrm{Al}_{4} \mathrm{Zn}_{2} \mathrm{Gd}_{9}$, (b) $\mathrm{Mg}_{85} \mathrm{Al}_{3} \mathrm{Zn}_{3} \mathrm{Gd}_{9}$ and (c) $\mathrm{Mg}_{85} \mathrm{Al}_{2} \mathrm{Zn}_{4} \mathrm{Gd}_{9}$ alloys after isothermal heat treatment at $450^{\circ} \mathrm{C}$ for $1000 \mathrm{~h}$. 
Table 4 Mg-TM-RE ratio (at\%) for each alloy after isothermal heat treatment at $450^{\circ} \mathrm{C}$ for $1000 \mathrm{~h}$ together with the ideal stoichiometric composition of the $14 \mathrm{H}$ and $18 \mathrm{R}$ LPSO phases. ${ }^{3)}$

\begin{tabular}{|c|c|c|c|}
\hline Element & $\mathrm{Mg}$ & $\begin{array}{c}\text { TM } \\
(\mathrm{Al}+\mathrm{Zn})\end{array}$ & $\mathrm{RE}(\mathrm{Gd})$ \\
\hline $\mathrm{Mg}_{85} \mathrm{Al}_{4} \mathrm{Zn}_{2} \mathrm{Gd}_{9}$ & 83.5 & 7.0 & 9.5 \\
\hline $\mathrm{Mg}_{85} \mathrm{Al}_{3} \mathrm{Zn}_{3} \mathrm{Gd}_{9}$ & 83.7 & 6.9 & 9.4 \\
\hline $\mathrm{Mg}_{85} \mathrm{Al}_{2} \mathrm{Zn}_{4} \mathrm{Gd}_{9}$ & 84.1 & 6.8 & 9.2 \\
\hline Ideal stoichiometry ${ }^{3)}$ & $\mathrm{Mg}$ & $\mathrm{TM}(\mathrm{Zn})$ & $\mathrm{RE}(\mathrm{Y})$ \\
\hline 14H LPSO & 83.3 & 7.1 & 9.5 \\
\hline 18R LPSO & 80.6 & 8.3 & 11.1 \\
\hline
\end{tabular}

Table 5 Comparison of $\mathrm{Al} / \mathrm{Zn}$ ratio for different alloy compositions and phases after isothermal heat treatment at $450^{\circ} \mathrm{C}$ for $1000 \mathrm{~h}$.

\begin{tabular}{c|cccccc}
\hline \multirow{2}{*}{ Actual composition (at\%) } & \multicolumn{5}{|c}{$\mathrm{Al} / \mathrm{Zn}$ ratio } \\
\cline { 2 - 7 } & $\begin{array}{c}\text { Alloy } \\
\text { composition }\end{array}$ & $\begin{array}{c}14 \mathrm{H} \\
\text { LPSO }\end{array}$ & $\begin{array}{c}18 \mathrm{R} \\
\text { LPSO }\end{array}$ & $\mathrm{Al} 2 \mathrm{Gd}$ & $\alpha-\mathrm{Mg}$ \\
\hline \hline $\mathrm{Mg}_{87.3} \mathrm{Al}_{3.6} \mathrm{Zn}_{2.0} \mathrm{Gd}_{7.4}$ & 1.7 & 1.6 & 1.6 & 20.3 & 0.13 \\
\hline $\mathrm{Mg}_{85.5} \mathrm{Al}_{3.0} \mathrm{Zn}_{3.0} \mathrm{Gd}_{8.5}$ & 1.0 & 1.1 & 1.2 & 10.7 & 0.03 \\
\hline $\mathrm{Mg}_{85.7} \mathrm{Al}_{2.0} \mathrm{Zn}_{4.0} \mathrm{Gd}_{8.3}$ & 0.5 & 0.6 & 0.7 & 7.9 & 0.02 \\
\hline
\end{tabular}

those based on the actual alloy compositions are summarized in Table 5. Figure 8 shows the $\mathrm{Al} / \mathrm{Zn}$ ratio for each phase as a function of that based on the alloy composition. It is noteworthy that the relationship is almost linear for the LPSO phases, but not for the $\alpha-\mathrm{Mg}$ and $\mathrm{Al}_{2} \mathrm{Gd}$ phases. This implies that $\mathrm{Al}$ and $\mathrm{Zn}$ atoms can easily substitute for each other at the same sites in $\mathrm{L1}_{2}$ clusters in the LPSO phase, whereas this is difficult in the $\alpha-\mathrm{Mg}$ and $\mathrm{Al}_{2} \mathrm{Gd}$ phases. As seen in Figs. 1, 4, 5 and 7, the fraction of the LPSO phase increases with increasing $\mathrm{Zn}$ content. This is attributed to destabilization of the $\mathrm{Al}_{2} \mathrm{Gd}$ phase in $\mathrm{Zn}$-rich alloys relative to the LPSO phase because of the difficulty of $\mathrm{Zn}$ substitution for Al. In Zn-rich alloys, $\mathrm{Al}_{2} \mathrm{Gd}$ is considered to be no longer one of the primary phases that suppress the formation of the LPSO phase during solidification in $\mathrm{Mg}-\mathrm{Al}-\mathrm{Gd}$ alloys. Similarly, the $\mathrm{Mg}_{3} \mathrm{Gd}$ phase present in the lamellar regions only in the as-cast state is thought to have almost no Al solubility and to become less stable with increasing $\mathrm{Al}$ content. This implies that the addition of $\mathrm{Al}$ to $\mathrm{Mg}-\mathrm{Zn}-\mathrm{Gd}$ alloys results in the relative stabilization of the LPSO phase. Therefore, a transition from Type II to Type I is expected because the $\mathrm{Mg}_{3} \mathrm{Gd}$ is considered to be no longer one of the primary phases that suppress the formation of the LPSO phase during solidification in $\mathrm{Mg}-\mathrm{Zn}-\mathrm{Gd}$ alloys. It can therefore be concluded that the relative destabilization of competing phases may be the main factor determining the type of LPSOcontaining $\mathrm{Mg}$ alloy formed.

\section{Concluding Remarks}

$\mathrm{Mg}-\mathrm{Al}-\mathrm{Zn}-\mathrm{Gd}$ quaternary alloys were investigated to clarify the type (Type I or Type II) of LPSO phase formed and to discover what factors determine the LPSO phase. The main conclusions of the present study are as follows.

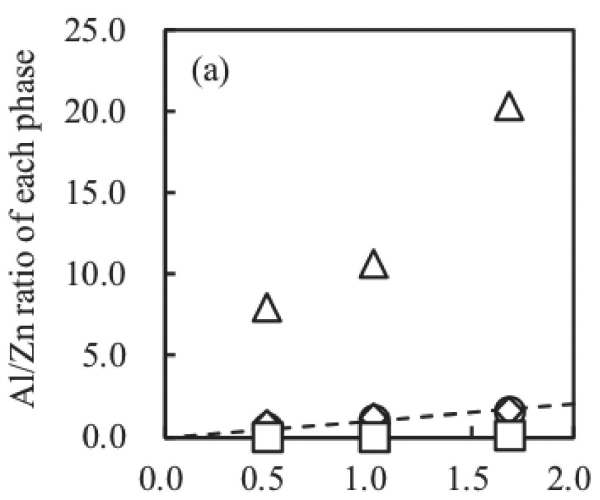

$\mathrm{Al} / \mathrm{Zn}$ ratio of alloy compositions

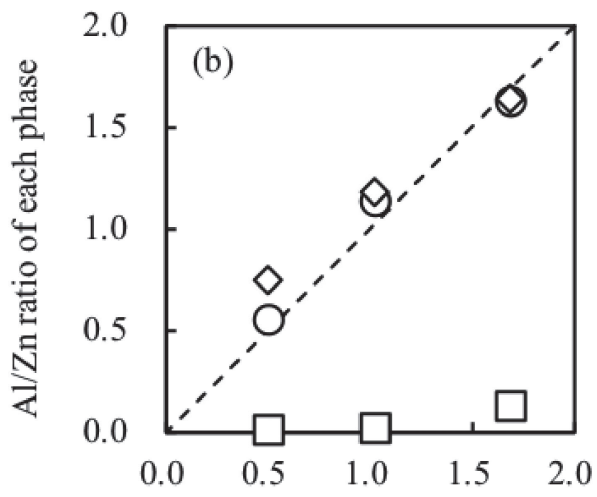

$\mathrm{Al} / \mathrm{Zn}$ ratio of alloy compositions

$\begin{array}{ll}\bigcirc 14 \mathrm{H} \text { LPSO } & \triangle \mathrm{Al} 2 \mathrm{Gd} \\ \diamond 18 \mathrm{R} \text { LPSO } & \square \alpha-\mathrm{Mg}\end{array}$

Fig. 8 Relationship between $\mathrm{Al} / \mathrm{Zn}$ ratio for actual alloy composition and that for each phase in the alloys after isothermal heat treatment at $450^{\circ} \mathrm{C}$ for $1000 \mathrm{~h}$. (b) is a magnified version of (a).

(1) Addition of $\mathrm{Zn}$ to a Type II ternary $\mathrm{Mg}-\mathrm{Al}-\mathrm{Gd}$ alloy or addition of $\mathrm{Al}$ to a Type II ternary $\mathrm{Mg}-\mathrm{Zn}-\mathrm{Gd}$ alloy results in a Type I quaternary $\mathrm{Mg}-\mathrm{Al}-\mathrm{Zn}-\mathrm{Gd}$ alloy.

(2) The chemical composition of the 18R LPSO phases in the as-cast quaternary alloys is about $\mathrm{Mg}_{90} \mathrm{TM}_{4} \mathrm{RE}_{6}$, in which the $\mathrm{Mg}$ content is much larger than the stoichiometric value.

(3) The $14 \mathrm{H}$ LPSO phase is considered to be an equilibrium phase at $450^{\circ} \mathrm{C}$ for the quaternary alloys employed in the present study.

(4) $\mathrm{Al}$ and $\mathrm{Zn}$ atoms easily substitute for each other in the LPSO phase, whereas this is difficult in the $\alpha-\mathrm{Mg}$, $\mathrm{Al}_{2} \mathrm{Gd}$ and $\mathrm{Mg}_{3} \mathrm{Gd}$ phases, suggesting relative destabilization of these phases by the additional elements ( $\mathrm{Al}$ or $\mathrm{Zn})$.

(5) The relative stability of the LPSO phase against competing phases such as $\mathrm{Al}_{2} \mathrm{Gd}$ and $\mathrm{Mg}_{3} \mathrm{Gd}$ may be the main factor determining the type of LPSOcontaining $\mathrm{Mg}$ alloy formed.

\section{Acknowledgements}

The authors would like to thank Mr. Keiichi Ono at Hokkaido University of Science for his support with sample 
preparation. A part of this work was supported by JSPS KAKENHI for Scientific Research on Innovative Areas "MFS Materials Science" (Grant Numbers JP18H05482).

\section{REFERENCES}

1) Y. Kawamura, K. Hayashi, A. Inoue and T. Masumoto: Mater. Trans 42 (2001) 1172-1176.

2) E. Abe, Y. Kawamura, K. Hayashi and A. Inoue: Acta Mater. 50 (2002) 3845-3857.

3) S. Yoshimoto, M. Yamasaki and Y. Kawamura: Mater. Trans. 47 (2006) 959-965.

4) Y. Kawamura, T. Kasahara, S. Izumi and M. Yamasaki: Scr. Mater. 55 (2006) 453-456.

5) T. Itoi, K. Takahashi, H. Moriyama and M. Hirohashi: Scr. Mater. 59 (2008) 1155-1158

6) F. Miyakawa, K. Ikeda, S. Miura, T. Horiuchi and S. Minamoto: Proc The 10th International Conference on Magnesium Alloys and Their Applications, (2015) pp. 345-349.
7) S. Miura, F. Miyakawa, K. Ikeda, T. Horiuchi, T. Itoi and S. Minamoto: Proc. The 3rd International Symposium on Long-Period Stacking Ordered Structure and Its Related Materials 2016 (LPSO2016), (Kyoto, 2016).

8) J. Gröbner, A. Kozlov, X.-Y. Fang, S. Zhu, J. Nie, M.A. Gibson and R. Schmid-Fetzer: Acta Mater. 90 (2015) 400-416.

9) D. Egusa and E. Abe: Acta Mater. 60 (2012) 166-178.

10) Y. Kawamura and M. Yamasaki: Mater. Trans. 48 (2007) 2986-2992.

11) Y.J. Wu, X.Q. Zeng, D.L. Lin, L.M. Peng and W.J. Ding: J. Alloy. Compd. 477 (2009) 193-197.

12) M. Yamasaki, M. Sasaki, M. Nishijima, K. Hiraga and Y. Kawamura: Acta Mater. 55 (2007) 6798-6805.

13) F. Miyakawa, S. Miura and K. Ikeda: Collected Abstracts of the 2016 Autumn Meeting of the Japan Inst. Metals and Materials, (2016) S2.16.

14) H. Okamoto: J. Phase Equilib. 16 (1995) 281-282.

15) M. Yamasaki, M. Matsushita, K. Hagihara, H. Izuno, E. Abe and Y. Kawamura: Scr. Mater. 78-79 (2014) 13-16.

16) K. Kishida, K. Nagai, A. Matsumoto, A. Yasuhara and H. Inui: Acta Mater. 99 (2015) 228-239. 